\title{
FILANTROPI KRISTEN: RESPONS TUBUH KRISTUS DALAM MENGATASI KEMISKINAN PADA MASA PANDEMI COVID-19 \\ BERDASARKAN KISAH PARA RASUL 2:44-45
}

\author{
Gde Ngurah Reza Rizaldy; Kayla Nathania Thayeb; Davin G. Sitompul \\ STT Ekumene Jakarta; STT Ekumene Jakarta \\ Mal Artha Gading Lt. 3, Jl. Artha Gading Selatan No 1, Jakarta Utara \\ E-mail: reza_25@sttekumene.ac.id; kayla.nathania@sttekumene.ac.id ; davin@sttekumene.ac.id
}

\begin{abstract}
ABSTRAK
Kemiskinan bukanlah persoalan baru dalam konteks kehidupan di Indonesia. Ironisnya, kemajuan zaman yang ada tidak berhasil mengatasi isu ekonomi ini. Terlihat dari angka kemiskinan yang kian bertambah, dan justru diperparah dengan kehadiran pandemi COVID-19. Untuk menyikapi isu ekonomi ini, kehidupan jemaat Kristen mula-mula menunjukkan keberhasilannya dalam mengatasi kemiskinan, yang dibuktikan dalam Kisah Para Rasul 2:44-45. Dengan demikian, artikel ini bertujuan untuk merumuskan suatu konsep yang disebut dengan Filantropi Kristen, sebagai solusi dalam menyikapi kesulitan ekonomi yang dialami masyarakat, khususnya dalam lingkungan Gereja. Sehingga secara kontekstual, penelitian ini bermanfaat untuk membuka perspektif individu dan Gereja dalam melihat, sekaligus menanggulanginya dengan menerapkan konsep Filantropi Kristen yang ditinjau dari perspektif Perjanjian Baru. Penelitian ini menggunakan metode kualitatif melalui kajian hermeneutika. Hasil penelitian menemukan bahwa konsep filantropi ini mendorong Gereja untuk merespons masalah perekonomian yang dialami dengan menjalankan pelayanan secara menyeluruh atau merata, baik pelayanan batiniah maupun lahiriah khususnya kepada kaumkaum marginal.
\end{abstract}

Kata kunci; COVID-19; Filantropi Kristen; Injil Lukas; Kemiskinan; Kisah Para Rasul

\begin{abstract}
ABSTRAC
Poverty is not a new problem in the context of life in Indonesia. Ironically, the current progress has not succeeded in overcoming this economic issue. This can be seen from the increasing poverty rate, and even worse by the presence of the COVID-19 pandemic. To address this economic issue, the life of the early Christian congregation showed its success in overcoming poverty, as evidenced in Acts 2:44-45. Thus, this article aims to formulate a concept called Christian Philanthropy, as a solution in addressing the economic difficulties experienced by the community, especially in the Church environment. So contextually, this research is useful for opening the perspective of individuals and the Church in seeing, as well as overcoming it by applying the concept of Christian Philanthropy which is viewed from the perspective of the New Testament. This research uses qualitative methods through hermeneutic studies. The results of the study found that the concept of philanthropy encourages the Church to respond to economic problems experienced by carrying out services comprehensively or evenly, both
\end{abstract}


inwardly and outwardly, especially to marginalized groups.

Keywords; COVID-19: Christian Philanthropy; Luke's Gospel; Poverty; Acts

\section{PENDAHULUAN}

Secara global, dunia memiliki masalah-masalah dalam beberapa bidang yang belum juga mencapai titik terang; Ketegangan geopolitik, perubahan iklim yang berdampak pada keberlangsungan hidup sehari-hari, permasalahan sosial ekonomi, serta kehadiran pandemi Covid-19 yang ikut menambah buntut panjang dari permasalahan sosial yang ada. Hal-hal ini tentunya berpengaruh pada kehidupan secara global bagi manusia pada masa sekarang ini, dan jika tidak dapat diselesaikan dengan baik dan tepat, maka berpotensi memberi dampak lebih besar pada masa yang akan datang.

Pada Maret 2020, Badan Pusat Statistik (BPS) menunjukkan \%tase penduduk miskin sebesar 9,78 \%, yang berarti meningkat 0,56\% terhadap September 2019 dan 0,37 \% terhadap Maret 2019. Kasus lain terlihat dari jumlah penduduk miskin pada Maret 2020 yang membilang 26,42 juta orang. Hal ini berarti ada peningkatan 1,63 juta orang terhadap September 2019 dan 1,28 juta orang terhadap Maret 2019. Demikian perlu diingat bahwa peningkatan angka kemiskinan di daerah perkotaan berbeda dengan pedesaan. Terlihat dari \%tase di perkotaan pada September 2019 sebesar 6,59 $\%$, naik menjadi 7,38 \% pada Maret 2020. Sedangkan di pedesaan sebesar 12,60 \% pada September 2019, naik menjadi 12,82 \% pada Maret 2020. Dengan ini, jelas bahwa kemiskinan merupakan persoalan ekonomi yang begitu mendesak, sulit untuk ditanggulangi, ataupun diselesaikan hingga saat ini. "Persoalan kemiskinan memang diperparah oleh kehadiran COVID-19." Pernyataan ini disetujui oleh the world bank dalam menyajikan prediksi terhadap apa yang dapat terjadi pada tahun 2021. Prediksi tersebut memperlihatkan akan terjadi penambahan sekitar 150 juta orang yang dapat diklasifikasikan pada level sangat miskin (extreme poor), akibat adanya pandemi global ini (The World Bank, 2020). Kecenderungan yang sama diperlihatkan oleh Indonesia. Tampak dari proyeksi pertumbuhan ekonomi pada kuartal I tahun 2020 yang seharusnya mencapai angka 4,6\%, nyatanya hanya menembus angka 2,97\%, menurut Badan Pusat Statistik. Hal ini dipengaruhi oleh kehadiran COVID-19 yang menjadi ancaman nyata bagi kelangsungan hidup dunia, khususnya masyarakat menengah ke bawah. Pasalnya, pandemi ini mengakibatkan terhambatnya roda pergerakan ekonomi 
yang ada. Salah satu faktor penyebabnya adalah kebijakan social distancing yang berujung pada sistem lockdown, sebagai langkah yang harus dilakukan pemerintah sebagai usaha untuk meminimalisir penyebaran virus antar-individu.

Hasil Survei Sosial Demografi COVID-19 yang dilakukan oleh BPS pada 1 Juni 2020 dengan total 87.379 responden, menunjukkan bahwa sebanyak 2,52\% responden mengalami Pemutusan Hubungan Kerja (PHK) sebagai dampak dari COVID-19 terhadap perusahaan yang ada. Jika ditelusuri berdasarkan jenis kelamin, sebanyak 1.87 $\%$ responden perempuan yang menjadi korban PHK, sedangkan 3,18 \% bagi responden laki-laki. Tidak hanya itu, 18,34 \% pekerja dicutikan. Melalui survei ini juga, COVID19 terbukti berdampak pada pendapatan masyarakat pekerja. Tertera bahwa sebanyak $63,16 \%$ karyawan yang dicutikan mengalami penurunan pendapatan. Namun, 36,84 \% responden yang masih bekerja pun ternyata merasakan dampak penurunan pendapatan yang diakibatkan oleh COVID-19. Jika dibagi per banyaknya pendapatan, responden yang berpendapatan dibawah Rp 1, 8 juta/bulan, ada sebanyak 70,53 \% yang merasakan dampak penurunan pendapatan ini. Sedangkan, \%an yang merasakan dampak COVID-19 bagi mereka yang berpendapatan di atas Rp. 7,2 juta/bulan adalah 30,34 \%. Untuk itu, terlihat bahwa dampak COVID-19 malah lebih dirasakan bagi mereka yang berpendapatan rendah (Putranto et al., 2020).

Melihat urgensi masalah yang diakibatkan oleh COVID-19 ini, pemerintah sudah berupaya dengan memberikan subsidi pangan dan kemudahan dalam akses bidang kesehatan, pendidikan, dan ekonomi (Kartu Indonesia Pintar, Kartu Indonesia Sehat, dan Kartu Indonesia Sejahtera) bagi masyarakat kelas bawah dalam memerangi permasalahan ekonomi ini. Upaya ini pun terus berlanjut hingga masa pandemi COVID-19. Pemerintah berupaya memberikan keringanan kepada masyarakat menengah ke bawah dengan memberikan beberapa tindakan seperti; Bantuan sembako, Bantuan Langsung Tunai (BLT), insentif tarif listrik, bantuan insentif melalui kartu prakerja, bantuan subsidi gaji untuk karyawan, Bantuan Langsung Tunai (BLT) bagi Usaha Mikro Kecil Menengah, tunjangan pulsa bagi Aparatur Sipil Negara (ASN), serta kuota internet gratis kepada siswa, mahasiswa, guru, dan dosen selama pembelajaran jarak jauh (Chusna Farisa, 2020).

Melihat upaya pemerintahan di atas, seharusnya umat Kristen sebagai "Tubuh Kristus" dapat turut berperan dalam mengatasi persoalan kemiskinan ini. Hal ini 
merujuk pada bentuk pelayanan yang seharusnya menjangkau seluruh bidang kehidupan manusia. Dari pelayanan pemberitaan Firman hingga pelayanan diakonia, dalam hal ini turut serta mengentaskan masyarakat dari kemiskinan, layaknya pelayanan yang Tuhan Yesus lakukan. Pendapat yang sama dikemukakan oleh Wirata, bahwa Pelayanan Firman dan kepada orang miskin merupakan tugas yang sama-sama penting dalam berjemaat (Wairata, 2017). Henry Mugabe berpendapat, "Mereka yang telah diberkati harus menjadi berkat bagi orang lain daripada mengumpulkan kekayaan untuk tujuan egois sendiri." (Mugabe, 2014). Hal ini mencerminkan persekutuan "Tubuh Kristus" yang sejati. Berkaitan dengan hal tersebut, artikel ini bertujuan untuk merumuskan konsep Filantropi Kristen (cinta kasih kepada sesama, KBBI) dalam menanggapi persoalan kemiskinan yang ada dengan peduli terhadap sesama. Dalam hal ini akan dikaitkan dengan lensa kekristenan, khususnya pada Perjanjian Baru, yaitu dari Kisah Para Rasul 2:44-45 sebagai bukti keberhasilan dari jemaat mula-mula dalam memerhatikan sesama yang berkekurangan.

\section{METODE}

Dalam merumuskan konsep Filantropi Kristen, artikel ini menggunakan metode kualitatif melalui kajian hermeneutika dan pengumpulan data melalui studi literatur. Kisah Para Rasul 2:44-45 akan dibedah dengan teliti sesuai konteks historis dan latar belakang sosial budaya yang melekat di dalamnya. Artikel akan menggunakan dukungan literatur berupa tafsiran dan survei latar belakang sosial-budaya sebagai petunjuk bahasan dan analisis naratif ayat demi ayat, sembari melihat dimensi sosial Injil Lukas sebagai Injil yang terkait dengan kitab Kisah Para Rasul. Sebagaimana genre kitab adalah historis-teologis, capaian pembahasan akan berfokus untuk menemukan makna teologis yang aplikatif terhadap masa kini, dimana penelusuran tersebut akan menuju pada perumusan konsep kebajikan sosial yaitu "Filantropi Kristen" sebagai respons orang Kristen dalam menyikapi kemiskinan.

\section{HASIL DAN PEMBAHASAN}

\section{Dimensi Sosial Sekuel Injil Lukas dan Kisah Para Rasul}

Kisah Para Rasul 2:44-45 mencerminkan akan kehidupan komunitas orang percaya dengan rasa kekeluargaan yang tinggi, terlihat dari aktivitas menjual milik 
kepunyaan demi memenuhi kebutuhan komunitas tersebut (ay. 25). Hal ini tentu didasari pada pribadi Yesus yang memberi perhatian khusus kepada orang-orang miskin, terutama dalam Injil Lukas (Nainupu, 2014). Ini terbukti dari istilah $\pi \tau \omega \chi o ́ \varsigma$ (ptochos beserta turunannya) yang berarti miskin (the poor) ditulis sebanyak 34 kali dalam Perjanjian Baru, 10 kali dalam Lukas (Hakh, 2010), 5 kali dalam Matius dan Markus, serta 4 kali dalam Yohanes. Demikianlah, cara Lukas membawa pembaca untuk lebih peduli dengan isu kemiskinan sebagai salah satu tema dari pembahasan Injil ini, dengan korelasinya terhadap Kisah Para Rasul, yang sering disebut sekuel dari Injil Lukas (DeSilva, 2018).

Pada narasi awalnya, Lukas menampilkan doa Maria kepada Allah yang memerlihatkan kepedulianNya terhadap mereka yang tertindas (Trisna, 2020):

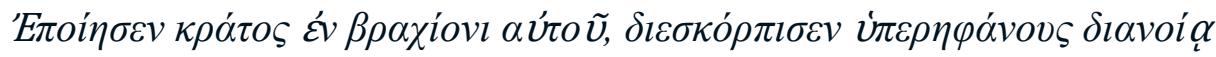

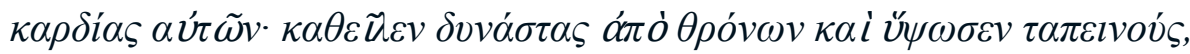

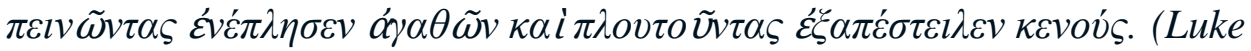
1:51-53, NA28)

He has done mighty deeds with His arm; He has scattered those who were proud in the thoughts of their heart. He has brought down rulers from their thrones, and has exalted those who were humble. HE HAS FILLED THE HUNGRY WITH GOOD THINGS; And sent away the rich emptyhanded." (Luke 1:51-53, NASB)

Ia memerlihatkan kuasa-Nya dengan perbuatan tangan-Nya dan menceraiberaikan orang-orang congkak hatinya; Ia menurunkan orang-orang yang berkuasa dari takhtanya dan meninggikan orang-orang yang rendah; Ia melimpahkan segala yang baik kepada orang yang lapar, dan menyuruh orang kaya pergi dengan tangan hampa (Luke. 1:51-53, TB)

Robert Trisna menjelaskan bahwa yang memiliki kedaulatan penuh akan status sosial seseorang adalah Yesus (Trisna, 2020). Dalam ayat-ayat di atas, terlihat bahwa Dia berkuasa meninggikan orang yang tertindas sekaligus merendahkan orang yang congkak. Dia mampu melimpahkan ( $\varepsilon \dot{v} \tilde{\pi} \lambda \eta \sigma \varepsilon v)$ orang yang lapar dengan segala hal yang baik. Namun Allah juga dapat menyuruh ( $\dot{\xi} \xi \alpha \pi \varepsilon ́ \sigma \tau \varepsilon 1 \lambda \varepsilon v$ ) orang kaya pergi dengan tangan hampa. Sehubungan dengan hal ini, Wright dan Bird berpendapat bahwa Allah dengan belas kasihanNya pun 
melayani orang miskin dengan janji "pembalikan" status yang kekal bersamaNya. Tidak sampai di situ, kedua penulis ini melanjutkan pendapatnya dengan pemaparan akan peran pelayanan terhadap orang miskin yang perlu direalisasikan dengan benar, seperti Yesus (Wright \& Bird, 2019).

Sejalan dengan hal di atas, Lukas 12:13-21 dapat dijadikan salah satu acuan mengenai dimensi sosial Injil Lukas. Terlihat Yesus memberikan perumpamaan, yang timbul karena seseorang dari kerumunan meminta Yesus untuk menyelesaikan permasalahan yang berkaitan dengan warisan (12:13). Namun alih-alih menjawab permasalahan itu, Yesus malah berfokus pada hal yang lebih mengarah pada suatu nasihat tentang ketamakan. Ada beberapa kemungkinan mengapa Yesus menjawab sesuatu hal yang tidak ditanyakan orang tersebut, salah satunya adalah karena fokus nasihat Yesus pada hal yang dapat menjerumuskan seseorang pada ketamakan yang masih berhubungan dengan kekayaan. Kemungkinan nasihat tersebut adalah sebagai pencegahan pola pikir yang salah, yaitu menempatkan materi pada posisi yang dapat memberhalakannya. Sejalan dengan hal ini, Constable mengatakan bahwa permintaan orang tersebut menyiratkan bahwa hidupnya akan lebih baik karena harta benda yang dapat diperolehnya. Tentu hal ini berlawanan dengan konsep kekristenan yang harus memfokuskan diri untuk mencari Tuhan (Kol. 3:1-4) (Constable, 2015). Oleh karena pertanyaan tersebut, Yesus menghadirkan perumpamaan tentang "orang kaya yang bodoh".

Kemudian Ia mengatakan kepada mereka suatu perumpamaan, kata-Nya: "Ada seorang kaya, tanahnya berlimpah-limpah hasilnya. Ia bertanya dalam hatinya: Apakah yang harus aku perbuat, sebab aku tidak mempunyai tempat di mana aku dapat menyimpan hasil tanahku. Lalu katanya: Inilah yang akan aku perbuat; aku akan merombak lumbunglumbungku dan aku akan mendirikan yang lebih besar dan aku akan menyimpan di dalamnya segala gandum dan barang-barangku. Sesudah itu aku akan berkata kepada jiwaku: Jiwaku, ada padamu banyak barang, tertimbun untuk bertahun-tahun lamanya; beristirahatlah, makanlah, minumlah dan bersenang-senanglah! Tetapi firman Allah kepadanya: Hai engkau orang bodoh, pada malam ini juga jiwamu akan diambil dari 
padamu, dan apa yang telah kausediakan, untuk siapakah itu nanti?

Demikianlah jadinya dengan orang yang mengumpulkan harta bagi dirinya sendiri, jikalau ia tidak kaya di hadapan Allah."

Yesus menggambarkan bagaimana orang kaya dalam narasi perumpamaan tersebut tersesat oleh karena pola pikirnya sendiri yang keliru, dimana seakan meyakini bahwa hidupnya hanya tentang kelimpahan kekayaan saja (Constable, 2015). Berkaitan dengan hal itu, Yesus mensejajarkan perilakunya dengan realitas yang dapat terjadi kapanpun, yaitu kematian. Kekayaan yang diperoleh dan dikumpulkan bagi dirinya sendiri adalah harta yang rapuh, dan tidak sebanding dengan kekayaan di hadapan Allah. Perumpamaan yang Yesus katakan kepada orang-orang tersebut bukan hendak mengatakan bahwa tidak ada seorang pun yang dapat memiliki kekayaan selama di bumi ini, tetapi pada sikap dan perilaku yang dilakukan setiap orang kaya yang disoroti oleh Yesus. Dalam konteks narasi tersebut, Yesus menunjukkan bahwa letak kebodohan dari seseorang adalah orientasi pendambaan seseorang; perkenanan dunia atau Tuhan. Sejalan dengan hal ini, Knight dalam bukunya mengatakan bahwa kebodohan tersebut adalah cerminan dari seseorang yang tidak menyadari realitas kekekalan yang akan datang, dengan tidak mempersiapkan diri dalam kewaspadaan mencari perkenanan Tuhan (Knight, 1998).

Beriringan dengan penjelasan di atas, bagian lanjutan yang terdapat pada

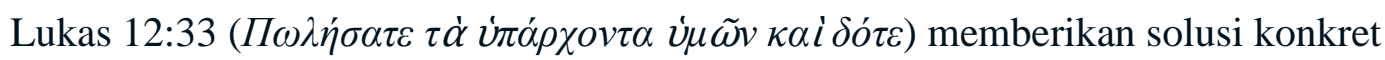
yang harus dilakukan, baik oleh setiap individu maupun gereja. Solusi konkret tersebut adalah perintah untuk menjual harta benda dan bersedekah. Tentu, ayat ini merujuk pada memanfaatkan sumber daya seseorang untuk orang lain juga. Hal ini sejalan dengan pernyataan Herry Susanto, bahwa pelayanan sesungguhnya adalah tidak melupakan mereka yang mengalami diskriminasi (Susanto, 2020). Pernyataan ini didukung oleh Henry Mugabe mengenai adanya simpati kepada sesama, bukan tidak peduli dan hanya memuaskan diri sendiri (Mugabe, 2014). Dengan melakukan ini, ayat ini juga menjanjikan akan harta duniawi yang dapat menjadi berkenan di hadapan Allah (Phillips, 2001). Hal ini merujuk pada pengelolaan kekayaan yang dimiliki untuk kepentingan Allah, dengan menjadi berkat bagi orang lain yang membutuhkan melalui pengelolaan kekayaan yang 
baik (Imeldawati, Tarigan, \& Sihombing, 2021). Oleh karenanya terlihat bahwa Injil Lukas menaruh perhatian pada hal kebaikan terhadap sesama, melalui salah satu lensa sosial yang ditunjukkan dalam Lukas pasalnya yang ke-12 ini.

\section{Penafsiran Kisah Para Rasul 2:44-45}

Kisah Para Rasul 2 adalah bagian kitab yang membahas tema besar, yaitu kelahiran Gereja di Yerusalem (Guthrie, 1990). Pada pasalnya yang kedua ini, kitab menampilkan proses kelahiran Gereja melalui peristiwa Pentakosta (2:1-13), hingga penjabaran cara hidup jemaat yang telah bertobat (2:41-47). Kelahiran Gereja yang dimaksudkan tentu berhubungan erat pada rencana Allah, yang mengakar pada rencana Ilahi $(2: 23 ; 4: 28 ; 26: 22-23)$ (DeSilva, 2018). Berkaitan dengan itu, bagian ini akan membahas respons jemaat mula-mula terhadap isu sosial yang timbul dalam bidang ekonomi yang juga sejalan mengikuti rencana kehendak Allah.

Schnabel dalam bukunya mengatakan setidaknya ada dua hal yang ditekankan oleh Lukas pada bagian ini (2:41-47). Pertama, Lukas menguraikan suatu keharmonisan bersama dalam kesatuan komunitas orang percaya. Kedua, praktik nyata dari persatuan orang percaya tergambar dari kesediaan mereka menggunakan harta benda untuk kepentingan bersama (Schnabel, 2012). Hal inilah yang menjadi ciri khas kehidupan jemaat mula-mula.

Cakupan Kisah Para Rasul 2:41-47 menyajikan beberapa poin yang berkaitan dengan cara hidup jemaat mula-mula. Keener dalam bukunya memberikan gagasan, bahwa terdapat poin inti dari cakupan tersebut melalui chiastic structure (Keener, 2020):

A Penginjilan yang efektif (melalui khotbah, 2:41)

B Ibadah dan makan bersama (2:42)

$$
\text { C Berbagi kepemilikan (2:44-45) }
$$

B' Ibadah dan makan bersama (2:46) A' Penginjilan yang efektif (melalui gaya hidup, 2:47) Struktur seperti ini memiliki fungsi sebagai penunjuk makna paralel dari barisbaris yang sejajar dan penyajian makna istimewa yang terdapat dalam konteks ayat dari baris-baris yang disajikan tersebut (Klein, 2017). Dalam hal ini, bagian 
klimaksnya ditunjukkan pada praktik saling berbagi kepemilikan untuk kepentingan bersama (2:44-45). Praktik ini adalah suatu buah dari koinonia yang sejati. Koinonia sendiri adalah praktik yang dapat eksis karena adanya partisipasi Roh Kudus, sejalan dengan peristiwa yang tengah berlangsung pada masa tersebut yaitu turunnya Roh Kudus atas mereka (Mahuze, 2016). Hal itu dapat terjadi karena mereka percaya. Kata percaya ( $\pi \iota \sigma \tau \varepsilon v ́ o v \tau \varepsilon \varsigma)$ dalam konteks ayat hadir dalam bentuk present active participle (“Acts 2:44 Greek Text Analysis,” 2004), dalam hal ini nuansa kata menunjukkan bahwa tindakan percaya yang terusmenerus terjadi perlu beriringan dengan bersatunya jemaat. Hal ini berkorelasi

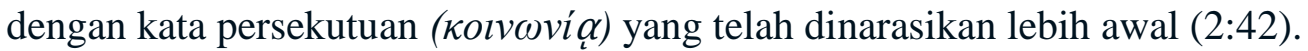

Percaya kepada Allah memberikan ruang partisipasi Roh Kudus bekerja dalam setiap orang yang menerimaNya. Lalu, partisipasi Roh Kudus tersebut melahirkan kasih nyata melalui kebaikan yang berjalan beriringan pada persekutuan bersama dalam kehendak Allah. Dengan kata lain, relasi vertikal diwujudkan melalui relasi horizontal yang disebut demonstrasi Kerajaan Allah (Soesilo, 2018). Oleh karenanya, kehidupan jemaat mula-mula menunjukkan, bahwa konsep ekonomi yang dijalankan bersifat komunal (Wahyudi, 2020). Hal ini berarti konsep hidup bersama yang dijalankan tidak hanya sebatas aspek lokusgeografis, tetapi bermakna lebih luas sehingga mencakup aspek ekonomi.

Penekanan dari kalimat, "Selalu ada dari mereka yang menjual harta miliknya, lalu membagi-bagikannya kepada semua orang sesuai dengan keperluan masing-masing," harus dipahami secara tepat. Kalimat tersebut tidak bermaksud untuk semua jemaat perlu menyerahkan seluruh harta milik mereka. Namun, ayat ini menjelaskan bahwa setiap orang yang mampu secara ekonomi hanya akan memberikan sesuatu jika ada kesulitan dalam jemaat (Sutoyo, 2014). Menambahkan hal tersebut, praktik sosial ini tidak bersifat komunis yang menyamaratakan seluruh anggotanya dalam bidang ekonomi. Hal tersebut tidak terjadi dalam kehidupan jemaat mula-mula, karena praktik ini tidak diatur secara resmi (Berkhof \& Enklaar, 2019). Jadi, kehidupan jemaat mula-mula menunjukkan secara gamblang bahwa mereka saling berbagi hidup dan turut ambil bagian pada jemaat yang membutuhkan pertolongan secara sukarela yang didasarkan pada kasih. 


\section{Filantropi Kristen}

Jika ditinjau dari segi etimologi, maka kata "filantropi" berasal dari bahasa Yunani “ $\varphi \imath \lambda \alpha \nu \theta \rho \omega \pi i \alpha$ ” dimana philo berarti cinta atau kebaikan dan anthropos berarti untuk umat manusia, sehingga secara kesatuan yang harafiah, filantropi

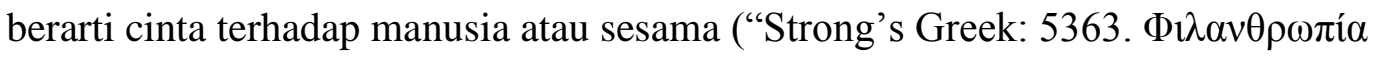
(Philanthrópia)," 2011). Menurut KBBI, filantropi sendiri berarti cinta kasih (kedermawanan dan sebagainya) kepada sesama. Dalam konteks masyarakat sendiri, filantropi ini dipahami dengan sedekah, sumbangan, atau bahasa inggris disebut charity, yaitu amal. Friedman mengartikan filantropi sebagai tindakan sukarela yang didorong oleh kecenderungan untuk menegakkan kepentingan publik (Friedman, 2002).

Dengan demikian, praktik filantropi pun sudah lama ada, bahkan sebelum ada kata "filantropi" itu sendiri. Istilah-istilah yang digunakan untuk mendeskripsikan filantropi kemudian tergantung pada setiap individunya, tetapi satu hal yang pasti adalah tujuan dari praktik filantropi ini berdasar pada rasa cinta yang diwujudkan dengan sikap peduli terhadap sesama secara merata, dimana persekutuan dan persatuan itu terjalin beriringan, terlihat dari mereka yang berkelimpahan membantu yang berkekurangan. Dengan kata lain, istilah tersebut dapat diwujudkan melalui solidaritas bersama umat manusia melalui berbagai tindakan (Sulek, 2010).

Dilihat dari definisi atau arti di atas, filantropi menjadi sesuatu hal yang erat dengan kehidupan sosial manusia, dimana di dalamnnya ada aspek sosialekonomi. Berkaitan dengan hal tersebut, Tubuh Kristus idealnya menerapkan secara nyata implementasi teologis seperti yang terdapat dalam Kisah Para Rasul 2:44-45. Konteks ayat tersebut menampilkan bahwa tindakan kebaikan bukan didasarkan pada pemenuhan hukum lisan maupun tertulis, tetapi dijalankan melalui ekspresi kasih yang digerakan oleh Roh Kudus. Hal ini menunjukkan bahwa iman tidak hanya berkutat pada hal liturgia dan ajaran, tetapi juga pada kehidupan orang-orang lain serta berbagai persoalannya (Yuono, 2020). Dengan kata lain, kontribusi atau tindakan nyata kepada sesama yang berkekurangan pun diperlukan. Inilah yang patut dicontoh dari jemaat mula-mula yang ada dalam 
Kisah Para Rasul 2:44-45, terlihat dari sifat tidak egois yang dimiliki jemaat mulamula dengan berbagi hidup kepada sesama secara tulus. Hal ini mencerminkan pada karakter Kristus yang ditunjukkan dalam dimensi dengan Lukas, yaitu peduli terhadap sesama menjadi poin yang esensial dan tak bisa dilupakan. Semangat filantropi seperti jemaat mula-mula inilah yang perlu dimiliki oleh individuindividu Kristen (gereja) sekarang dan seterusnya dalam menjalani kehidupan.

Dalam konteks sekarang, yang dikenal dengan sebutan tahun COVID-19, konsep filantropi Kristen ini perlu direalisasikan dan disadari secepatnya, agar setiap urgensi yang telah dijelaskan di bagian sebelumnya sedikitnya dapat tertanggulangi melalui umat Kristiani. Dengan begitu, cerminan karakter yang seperti Kristus pun dapat terlihat dari manusia. Namun lebih dari pada itu, manusia dapat hidup dengan keseimbangan ekonomi yang baik dan masalah global yang saat ini menjadi momok pun dapat berkurang.

\section{SIMPULAN}

Orang Kristen dalam segala zaman memiliki persoalannya masing-masing. Orang Kristen pada masa kini diperhadapkan pada realitas persoalan pandemi COVID19, dimana ekonomi mengalami kemerosotan yang menyebabkan timbulnya persoalan ekonomi khususnya pada golongan menengah ke bawah. Konsep Filantropi Kristen membawa Gereja untuk merespons secara nyata persoalan ini dengan memberikan pertolongan dalam bidang ekonomi. Oleh karenanya, pemisahan hal rohani atau batiniah (liturgi; ibadah; doa) dan lahiriah (Filantropi) adalah hal yang seharusnya pantang dilakukan. Semua hal tersebut harus secara utuh menyatu dalam spiritualitas setiap Tubuh Kristus. Dengan demikian, Tubuh Kristus secara nyata telah menghadirkan Kerajaan Allah kepada semua orang, secara khusus kepada kaum-kaum marginal melalui Filantropi Kristen.

\section{DAFTAR PUSTAKA}

Acts 2:44 Greek Text Analysis. (2004). Retrieved April 29, 2021, From Https://Biblehub.Com/Text/Acts/2-44.Htm

Berkhof, H., \& Enklaar, I. H. (2019). Sejarah Gereja. Jakarta: Bpk Gunung Mulia. 
Chusna Farisa, F. (2020). Melihat Efektivitas 9 Bantuan Dan Subsidi Pemerintah

Selama 6 Bulan Pandemi. Retrieved From

Https://Www.Kominfo.Go.Id/Content/Detail/32247/Bansos-Insentif-Hingga-

Vaksinasi-Jadi-Upaya-Pemerintah-Tangani-Pandemi/0/Berita_Satker

Constable, T. L. (2015). Thomas Constable's Notes On The Bible: Luke-John Volume 7 Of Constable's Notes On The Bible Series.

Desilva, D. A. (2018). An Introduction To The New Testament: Contexts, Methods \& Ministry Formation (Second Edition). Downers Grove: Intervarsity Press.

Friedman, L. J. (2002). Charity, Philanthropy, And Civility In American History. 20.

Guthrie, D. (1990). New Testament Introduction (4th Rev. Ed). Downers Grove, Ill: Inter-Varsity Press.

Hakh, S. B. (2010). Perjanjian Baru: Sejarah, Pengantar Dan Pokok-Pokok Teologisnya. Bandung: Bina Media Informasi.

Imeldawati, T., Tarigan, I. S., \& Sihombing, W. F. (2021). Sikap Waspada Terhadap Ketamakan Akan Kekayaan (Lukas 12:13-21). Areopagus : Jurnal Pendidikan Dan Teologi Kristen, 19(1), 121-134. Https://Doi.Org/10.46965/Ja.V19i1.608

Keener, C. S. (2020). Acts. Cambridge, United Kingdom: Cambridge University Press.

Klein, W. W. (2017). Introduction To Biblical Interpretation By William W. Klein.Pdf.

Knight, J. (1998). Luke’s Gospel. London ; New York: Routledge.

Mahuze, P. N. (2016). Studi Tentang Praksis Koinonia Umat Komunitas Basis Di

Paroki St. Theresia Buti Keuskupan Agung Merauke-Papua Selatan. 29.

Mugabe, H. (2014). Parable Of The Rich Fool: Luke 12:13-21. Review \& Expositor, 111(1), 67-73. Https://Doi.Org/10.1177/0034637313514799

Nainupu, M. (2014). Pelayanan Gereja Kepada Orang Miskin. 
Phillips, T. E. (2001). Reading Issues Of Wealth And Poverty In Luke-Acts. Lewiston, N.Y: Edwin Mellen Press.

Putranto, W. P. A., Larasaty, P., Kurniasih, A., Pratiwi, A. I., Riyadi, Saputri, V. G., \& Meilaningsih, T. (2020). Hasil Survei Sosial Demografi Dampak Covid-19 2020. Bps Ri. Retrieved From Https://Www.Bps.Go.Id/Publication/Download.Html?Nrbvfeve=Njy5y2iyztg2n dy3oddlntjkzde3mwm0\&Xzmn=Ahr0chm6ly93d3cuynbzlmdvlmlk13b1ymxpy2 f0aw9ulziwmjavmdyvmdevnjy5y2iyztg2ndy3oddlntjkzde3mwm012hhc2lslxn1c nzlas1zb3npywwtzgvtb2dyywzplwrhbxbhay1jb3zpzc0xos0ymdiwlmh0bww\%3 $\mathrm{d} \&$ Twoadfnoarfeauf=Mjayms0wni0xmiaymto1njoxmg\%3d $\% 3 \mathrm{~d}$

Schnabel, E. J. (2012). Acts: Zondervan Exegetical Commentary On The New Testament. Grand Rapids, Michigan: Zondervan.

Soesilo, Y. (2018). Pentakostalisme Dan Aksi Sosial: Analisis Struktural Kisah Para Rasul 2:41-47. Dunamis: Jurnal Teologi Dan Pendidikan Kristiani, 2(2), 136. Https://Doi.Org/10.30648/Dun.V2i2.172

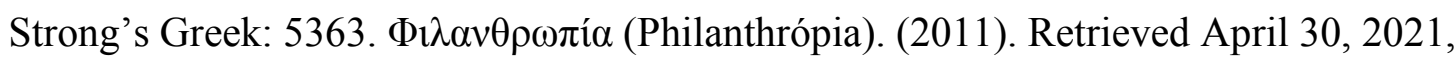
From Https://Biblehub.Com/Greek/5363.Htm

Sulek, M. (2010). On The Classical Meaning Of Philanthrôpía. Nonprofit And Voluntary Sector Quarterly, 39(3), 385-408. Https://Doi.Org/10.1177/0899764009333050

Susanto, H. (2020). Panggilan Sosial Gereja Berdasarkan Pelayanan Yesus Dalam Lukas 4:18-19: Sebuah Upaya Merevitalisasi Pelayanan Gereja. Veritas: Jurnal Teologi Dan Pelayanan, 19(1), 97-112.

Https://Doi.Org/10.36421/Veritas.V19i1.356 
Sutoyo, D. (2014). Gaya Hidup Gereja Mula-Mula Yang Disukai Dalam Kisah Para Rasul 2: 42-47 Bagi Gereja Masa Kini. 40.

The World Bank. (2020). Covid-19 To Add As Many As 150 Million Extreme Poor By 2021. Retrieved From Https://Www.Worldbank.Org/En/News/Press-

Release/2020/10/07/Covid-19-To-Add-As-Many-As-150-Million-ExtremePoor-By-2021

Trisna, R. P. (2020). Kaum Marginal Dalam Injil Lukas Dan Kisah Para Rasul. 11.

Wahyudi, A. (2020). Apa Itu Entrepreneurship, Theospreneurship, Spiritualpreneurship. Retrieved From Https://E-Journal.SttStar.Ac.Id/Index.Php/Asteros/Article/View/14

Wairata, M. (2017). Diakonia Transformatif Dalam Pengentasan Kemiskinan: Upaya Mentransformasi Pelayanan Gereja Terhadap Orang Miskin Dalam Konteks Gki Martin Luther Di Tanah Papua (Universitas Kristen Satya Wacana). Universitas Kristen Satya Wacana. Retrieved From Https://Repository.Uksw.Edu/Handle/123456789/13338

Wright, N. T., \& Bird, M. F. (2019). The New Testament In Its World: An Introduction To The History, Literature, And Theology Of The First Christians. London : Grand Rapids, Mi: Spck; Zondervan Academic.

Yuono, Y. R. (2020). Pertumbuhan Gereja Di Masa Pandemi. 10. 